\title{
Evaluation of demographic characteristics, and general disease state of patients affliated with home health care unit of Malatya State Hospital
}

\author{
Ersoy Oksuz ${ }^{1}$, Elif Onat' ${ }^{1}$, Andleeb Shahzadi ${ }^{2}$, Zeliha Yazici' ${ }^{2}$, Cumali Cetin ${ }^{3}$ \\ ${ }^{1}$ Department of Home Health Service, Malatya State Hospital, Malatya, Turkey; \\ ${ }^{2}$ Department of Medical Pharmacology, Istanbul University, Cerrahpasa Medical Faculty, Istanbul, Turkey; \\ ${ }^{3}$ Departmen of Infectious Diseases, Malatya State Hospital, Malatya, Turkey
}

\begin{abstract}
OBJECTIVE: Home Health Care Unit a unit provides health services for elderly, bedridden and individuals with chronic diseases at home along within the frame of the diagnosis, and treatments of the relevant experts. Therefore, it is intended to reduce the probable physical and emotional burden related to the patient that arise by commuting to the hospital, to increase the number of empty beds for other patients and to improve the living standard by reducing the risk of hospital infection. In this study, the demographic characteristics of housebound patients, their general disease and its relationship with age and gender was investigated.
\end{abstract}

METHODS: The following study was performed on 626 active patients of Malatya State Hospital Home Health Care Unit from January to November 2014. Data were analyzed using Microsoft Excel Program.

RESULTS: The study included 60.5\% $(n=379)$ female and 39.5\% $(n=247)$ male patients. The highest group consisted of patients with 80 years or above $37.7 \%(n=236)$. Cerebrovascular disease (CVD) $(n=95 ; 25.0 \%)$, senility $(n=56 ; 14.8 \%)$ and Alzheimer's disease $(n=50 ; 13.2 \%)$ were commonly observed in women. Male patients had CVD $(n=54 ; 21.8 \%)$, femur fracture or gonarthrosis which required surgery $(n=28 ; 11.3 \%)$, and fracture due to trauma or traffc accidents $(n=28 ; 11.3 \%)$, senility and Alzheimer's disease $(n=218.5 \%)$.

CONCLUSION: In recent years home health care units became even more important after the gradual increase in the elderly population and injuries due to accidents. This study can help to provide home health care units in a more effcient manner by educating the staff and relatives who take care of the patients.

Key words: Aging; alzheimer; cerebrovascular disease; home medicare.

$\mathrm{H}$ ealth care units at home provide necessary psychosocial, and medical support for elderly, and disabled individuals, patients with chronic dis- eases after their discharge from the hospital in their living environment, increase their standard of living, ensure more peaceful life for them, and alleviate the

Received: December 01, 2014 Accepted: December 18, 2014 Online: January 24, 2015

Correspondence: Dr. Ersoy OKSUZ. Malatya Devlet Hastanesi, Firat Mahhallesi, Hastane Caddesi Cosnuk Semet Poliklinigi Malatya, Turkey.

Tel: +90 422 - 3261569 e-mail: drugoksuz@hotmail.com

(c) Copyright 2014 by Istanbul Northern Anatolian Association of Public Hospitals - Available online at www.kuzeyklinikleri.com 
work burden of patient's relatives [1].

Home health care units were firstly implemented in the year 2005 with the release of a regulation by Ministry of Health entitled "Provision of Home Health Care Services", and published in the Turkish Official Gazette (issue \#25751) [2]. In compliance with the regulation released in the year 2010 the task of these units has been described as "The task of this unit is not to make a diagnosis, but to offer services of physical examination, analysis, medical care, and rehabilitation at home of the patient within the frame of the diagnosis made, and treatment planned previously by the specialists of the relevant branches. Besides it facilitates prescription of medical board reports for the $\operatorname{drug}(\mathrm{s})$ which should be used for a long time, and release of the reports for medical device, and materials. It also informs the patient, and his/her family about the tasks they would assume during the disease process, and provide training, and counselling about the disease, health care procedures, appropriate use of medical devices, and equipments that should be used at home [3].

Home health care units especially offer services to elder patients with chronic diseases, completely or partially bedridden patients at their home. By this means, it is aimed to obviate from material, and moral constraints which originate from frequent commuting between home, and the hospital, increase number of empty beds in the hospital, decrease the hospitalization expenditures, and the risk of nosocomial infection by early discharge of the patients from the hospital, provide moral support for the patients by their earlier return to their family environment, and raise their standard of living to its peak level, and protect them from contracting secondary diseases [4].

In Turkey, life span of elder population is increasing gradually. In the year 2005, 5\%, and in 2010 $7.9 \%$ of the Turkish population consisted of elderly people. In the year 2025, it is estimated to rise to 10 percent $[5,6]$. With the increase in the elder population, the number of individuals who need health care services at home will increase. With aging, incidence of chronic diseases also increases. In $90 \%$ of the individuals over the age of 65 , presence of one or more than one disease states have been reported. According to The World Health Organization
(WHO) $60 \%$ of all deaths in the world are caused by chronic diseases. Among these deaths, cardiovascular diseases lead the way followed by cancer-related deaths. Among fatal diseases for people over the age of 60 , ischemic heart disease, and cerebrovascular diseases take the first, and the second place, respectively [6]. Cerebrovascular disease (CVD) occupies an important place as for home health care units. In a report released by WHO in 2005, CVD is also responsible for $12.0 \%$ of all disease-related deaths. Besides CVD is responsible for $85 \%$ of all deaths caused by neurological diseases $[7,8]$. In a study performed in 2011 in Ordu University Training and Research Hospital within the context of Health Care Services At Home, CVD was detected as the most frequently seen disease [9]. Regarding their higher incidence, and also requirement for long-term health care, treatment, and rehabilitation of these patients by health care services at home gain gradually increasing importance.

One of the other two important problems is that in recent years the number of bedridden, and disabled patients have increased because of ever increasing rate of traffic accidents which necessitated fulfilling the needs of disabled individuals in the community. As an important issue, since many of these patients are young individuals, they should be reintigrated into society, their hospital stays, and treatment costs should be decreased. A study performed in 2002 revealed that $4.0 \%$ of disabled individuals in the community required health care services at home. Nearly $10.0 \%$ of them had reportedly a chronic disease $[10,11]$.

The objective of this study was to evaluate age, and gender of the patients, and diseases seen in patients who received active services in Malatya State Hospital Home Health Care Unit between January, and November 2014.

\section{MATERIALS AND METHODS}

For this study required approvals have been obtained from The Ethics Committee of Clinical Researches, and hospital administration of Yüzüncü Y1l University. Home Health Care Unit of Malatya State provide services from 2008 on. The patients who died since 2008 were excluded from the study, 


\begin{tabular}{|c|c|c|c|c|c|c|}
\hline \multirow[t]{2}{*}{ Age groups } & \multicolumn{2}{|c|}{ Women $n=379(60.5)$} & \multicolumn{2}{|c|}{ Men $n=247$ (39.5) } & \multicolumn{2}{|c|}{ Total $(n=626)$} \\
\hline & $\mathrm{n}$ & $\%$ & $n$ & $\%$ & $\mathrm{n}$ & $\%$ \\
\hline$\leq 49$ & 35 & 9.2 & 54 & 21.8 & 89 & 14.2 \\
\hline $50-59$ & 25 & 6.6 & 22 & 8.9 & 47 & 7.5 \\
\hline $60-69$ & 44 & 11.6 & 33 & 13.4 & 77 & 12.3 \\
\hline 70-79 & 108 & 28.5 & 69 & 28.0 & 177 & 28.3 \\
\hline$\geq 80$ & 167 & 44.0 & 69 & 28.0 & 236 & 37.7 \\
\hline
\end{tabular}

and medical files of 2800 patients who received services from this unit were screened. The patients whose death was reported during the study period, patients temporarily confined to bed (cases with bone fractures because of traffic accident or trauma, patients operated for various indications whose wounds were dressed or their injections were made), and completely cured patients who did not receive the services of the unit any more were excluded from the study, and demographic characteristics, and diseases of the remaining 991 patients were classified. The patients (226 female, and 139 male) who received the services of this unit before the year 2014 were not included in the study. A total of 626 active patients who were visited by the staff of the unit at their home, and received health care services were included in the study. This was a retrospective and descriptive study which enrolled all patient groups who consulted to Malatya State Hospital Home Health Care Unit. There was no sampling group created.

\section{Statistical analysis}

All data were evaluated in the Microsoft Excel program. All data were entered in a computerized system, then percent changes of each group were calculated based on total number of study participants, and separately for male, and female patients

\section{Limitation of the study}

The study included active patients who had received services within the year 2014. Although, high- er number of patients were included in our study, exclusion of the patients who were thought to be bedridden as understood from screening of patients'medical files, but couldn't receive the services of the Unit is a limitation of our study.

\section{RESULTS}

A total of 626 (female, $\mathrm{n}=379,60.5 \%$, and male, $\mathrm{n}=247 ; 39.5 \%$ ) patients were included in the study. Based on the age groups, number, and percentages of the female, and male patients are given in Table 1. Patients aged $\geq 80$ constituted the group with the highest number of patients $(n=236 ; 37.7 \%)$. The diseases seen in the patients who received health care services at home were prioritized, and classified as diseases, and disease groups which would confine the patients to bed. Secondly, concomitant diseases were evaluated separately. In female patients cerebrovascular diseases (CVDs) $(\mathrm{n}=95 ; 25.0 \%)$, senility $(n=56 ; 14.8 \%)$, and Alzheimer's disease $(n=50 ; 3.2 \%)$ were detected in respective number, and percentage of female patients as indicated in parentheses. Among male patients, cases with CVD $(n=54 ; 21.8 \%)$, operations with the indications of femoral fracture, or gonarthrosis $(n=28 ; 11.3 \%)$, patients with fractures caused by traumatic events or traffic accidents $(n=28 ; 11.3 \%)$, finally Alzheimer's disease, and senility $(n=21 ; 8.5 \%)$ were detected (Table 2). Although, the patients in the advanced age group were mostly confined to bed because of chronic diseases, in the group aged 49 years or younger, 
TABLE2. Diseases seen in patients who were benefiting from home health care service units

\begin{tabular}{|c|c|c|c|c|c|c|}
\hline \multirow[t]{2}{*}{ Diseases } & \multicolumn{2}{|c|}{ Women } & \multicolumn{2}{|c|}{ Men } & \multicolumn{2}{|c|}{ Total } \\
\hline & $\mathrm{n}$ & $\%$ & $\mathrm{n}$ & $\%$ & $\mathrm{n}$ & $\%$ \\
\hline Cerebrovascular diseases & 95 & 5.0 & 54 & 21.8 & 149 & 23.8 \\
\hline Senility & 56 & 14.8 & 21 & 8.5 & 77 & 12.3 \\
\hline Alzheimer & 50 & 13.2 & 21 & 8.5 & 71 & 11.3 \\
\hline Femurai fracture, gonarthrosis, osteoporosis & 41 & 10.8 & 28 & 11.3 & 69 & 11.0 \\
\hline CHF & 41 & 10.8 & 17 & 6.9 & 58 & 9.3 \\
\hline Oncological diseases & 23 & 6.0 & 21 & 8.5 & 44 & 7.0 \\
\hline Spastic disability, MR or cerebral palsy & 19 & 5.0 & 22 & 8.9 & 41 & 6.5 \\
\hline Trauma-Fracture following TA & 12 & 3.0 & 28 & 11.3 & 40 & 6.4 \\
\hline Multiple sclerosis & 8 & 2.0 & 2 & 0.8 & 10 & 1.6 \\
\hline Amiotrophic lateral sclerosis & - & - & 3 & 1.2 & 3 & 0.5 \\
\hline Epilepsy, psychosis, parkinsonism & 6 & 1.5 & 8 & 3.2 & 14 & 2.2 \\
\hline Myopathy, neuropathy & 4 & 1.0 & 7 & 2.3 & 11 & 1.7 \\
\hline Encephalitis as a result of MI & 1 & 0.25 & 5 & 2.0 & 6 & 0.9 \\
\hline COPD & 6 & 1.5 & 6 & 2.4 & 12 & 1.9 \\
\hline CRF & 6 & 1.5 & 1 & 0.4 & 7 & 1.1 \\
\hline Obesity & 6 & 1.5 & - & - & 6 & 0.9 \\
\hline SSPE, GB, TBC, PAD, ELP, LDH & 5 & 1.25 & 3 & 1.2 & 8 & 1.2 \\
\hline
\end{tabular}

ELP: Elephantiasis; GB: Gullain-Barré syndrome; CHF: Chronic renal failure; CHF: Chronic heart failure; COPD: Chronic obstructive pulmonary disease; LDH: Lumbar discal hernia; MI: Myocardial infarction; MR: Mentally retarded; PAD: Peripheral artery disease; SSPE: Subacute sclerosing panencephalitis; TBC: Tuberculosis; TA: Traffic accident.

more frequently the patients with congenital anomalies, congenital diseases or patients who experienced traumatic events, and traffic accidents were confined to bed. Majority of the young men who received services of the Unit had fractures secondary to traumatic events or traffic accidents (female 12, and male 28).

Distribution (\%) of CVD, senility, and Alzheimer's disease seen in individuals benefiting from the Home Health Care Unit is seen in Table 3. CVD was most frequently seen in the age group of $70-79$ years $(43.0 \%)$, then in patients aged 80 and above (34\%). Female patients with left hemiplegia $(52.6 \%)$ were more numerous than those with right hemiplegia. However among men the rates of left, and right hemiplegia were equal (46.2\%). Senility as a cause of confinement to bed was seen mostly in patients aged 80 and over (83.1\%). In 52.5\% ( $n=42)$ of the patients, any chronic disease was not detected excepting senility. As chronic disease, hypertension was detected in 16 (28.6\%) female, and 8 (38.0\%) male patients. Alzheimer's disease was mostly seen in patients aged 80, and over (64.8\%). Forty-four (65.0\%) patients had only Alzheimer's disease without any other chronic disease. Concomitant HT was present in 13 female, and 7 male patients.

As asecondary chronic diseases, hypertension $(n=196 ; 31.3 \%)$, and diabetes mellitus $(n=86$; $13.7 \%)$ were seen. Decubitus ulcer which is the most important health problem in bedridden patients was seen in $48(7.6 \%)$ patients.

\section{DISCUSSION}

Most of our study population were elder, and chronic patients. Patients' requirement for care, and health services increases with age. A study performed in Eskişehir, revealed that people in need of care constituted $3.7 \%$ of the total population of the city. While people aged above 65 , comprised $53.2 \%$ of the total 
TABLE 3. Distribution, and rates of CVD, senility, and Alzheimer's disease among age groups seen in patients who were benefiting from home health care servives

\begin{tabular}{|c|c|c|c|c|c|c|c|c|c|c|c|c|}
\hline \multirow[t]{2}{*}{ Disease (Gender) } & \multicolumn{2}{|c|}{$\leq 49$} & \multicolumn{2}{|c|}{$50-59$} & \multicolumn{2}{|c|}{$60-69$} & \multicolumn{2}{|c|}{$70-79$} & \multicolumn{2}{|c|}{$\geq 80$} & \multicolumn{2}{|c|}{ Total } \\
\hline & $\mathrm{n}$ & $\%$ & $\mathrm{n}$ & $\%$ & $\mathrm{n}$ & $\%$ & $\mathrm{n}$ & $\%$ & $\mathrm{n}$ & $\%$ & $\mathrm{n}$ & $\%$ \\
\hline \multicolumn{3}{|l|}{ Left hemiplegia (Female) } & & & 8 & 16.0 & 20 & 40.0 & 22 & 44.0 & 50 & 52.6 \\
\hline \multicolumn{3}{|l|}{ Left hemiplegia (Male) } & 1 & 4.0 & 4 & 16.0 & 10 & 40.0 & 10 & 40.0 & 25 & 46.2 \\
\hline \multicolumn{3}{|l|}{ Right hemiplegia (Female) } & 2 & 5.3 & 6 & 15.8 & 16 & 42.1 & 14 & 36.8 & 38 & 40.0 \\
\hline Right hemiplegia (Male) & 1 & 4.0 & 1 & 4.0 & 4 & 16.0 & 16 & 64.0 & 3 & 12.0 & 25 & 46.2 \\
\hline Tetraplegia (Female) & 1 & 14.3 & 2 & 28.6 & 1 & 14.3 & 1 & 14.3 & 2 & 28.6 & 7 & 7.3 \\
\hline \multicolumn{5}{|l|}{ Tetraplegia (Male) } & 2 & 50.0 & 1 & 25.0 & 1 & 25.0 & 4 & 7.4 \\
\hline Total & 2 & 1.3 & 6 & 4.0 & 25 & 16.8 & 64 & 43.0 & 52 & 35.0 & 149 & 23.8 \\
\hline \multicolumn{5}{|l|}{ Elder women } & 1 & 1.8 & 8 & 14.3 & 47 & 83.9 & 56 & 14.8 \\
\hline \multicolumn{5}{|l|}{ Elder men } & 1 & 4.7 & 3 & 14.3 & 17 & 81.5 & 21 & 8.5 \\
\hline \multicolumn{5}{|l|}{ Total } & 2 & 2.6 & 11 & 14.3 & 64 & 83.1 & 77 & 12.3 \\
\hline \multicolumn{5}{|c|}{ Alzheimer's disease (Female) } & 5 & 10.0 & 12 & 24.0 & 33 & 66.0 & 50 & 13.2 \\
\hline \multicolumn{5}{|c|}{ Alzheimer's disease (Male) } & 1 & 4.8 & 7 & 33.2 & 13 & 62.0 & 21 & 8.5 \\
\hline \multicolumn{5}{|l|}{ Total } & 6 & 8.5 & 19 & 27.8 & 46 & 64.8 & 71 & 11.3 \\
\hline
\end{tabular}

population of the city [11]. In a study performed both in 1997, and 2004 in Austria, median age of the male, and female population benefiting from health care units in the years 1997, and 2004 was detected as 72 vs. 76 , and 79 vs 81 years, respectively [12]. In the year 2011, in the study performed by Home Health Care Service Unit of Ordu University Training and Research Hospital most frequently (38.4\%) patients aged 80 years, and above were detected [9]. We also obtained similar results in our study. Most of our study population were aged 80 , and above (37.7\%). In a study performed in Austria, female patient population $(71.1 \%)$ was indicated to be more numerous than male patients [12]. Similarly in a study performed by the Home Health Care Unit of a Turkish public hospital, female patients were observedly higher (63.8\%) in number [13]. In a study performed in Ordu University Training and Research Hospital, male patient population was reportedly more numerous $(58.4 \%)$ than female patients [9]. In compliance with the other two studies mentioned above, in our study, the percentage of female patients were $21.0 \%$ higher than male patients.
Although the number of male, and female patients in a study performed in the year 2011 in Mamak district were nearly the same to what we detected in our study, number of patients in age groups differred. In this study the highest number of patients were reported in the 45-60 age group, then in the 35-40 age group [10].

In patients receiving health services at home, more frequently cardiac, orthopedic, respiratory problems, and DM were encountered $[11,14]$. Based on the data provided by local health authority of Eskişehir, Alzheimer's disease, dementia, and cerebrovascular diseases were reported in $50 \%$ of those receiving health care at home [11]. In a study conducted in Austria, mostly central nervous system (CNS), musculoskeletal (degenerative, posttraumatic), and cardiovascular diseases were observed [12]. Similar outcomes have been also revealed in a study performed in Ordu University Training and Research Hospital. In their study most frequently CVD was seen, followed by Alzheimer's disease [9]. Our outcomes were similar to our data. CNS-related CVD, Alzheimer's diseases, operated femoral fracture, 
gonarthrosis, osteoporosis, and CHF consisted 4 of 5 most frequently seen diseases. Our study differs from others, in that senility was the most frequently seen condition after CVD. Nearly, half of these patients any chronic disease was not found.

CVD is responsible for $14.5 \%$, and $15.7 \%$ of the mortalities among men, and women, respectively [7]. CVD is the most important disease which causes restriction of mobility in individuals above 40 years of age. Ischemic stroke is more frequently seen in elder patients. Since life span of women is longer, they appear to have higher risk of dying from an ischemic disease, and risk of stroke during their life time $[15,16,17]$. The outcomes of our study are compatible with these findings. CVD is the most frequently seen disease, especially in women. Beginning from the age group of 50-59, its incidence increased in both genders. Only one female, and one male patient were younger than 50 years of age. In men it is most often seen in the age group of 70-79 years, while its incidence decreased almost 50 percent. In women it is most often seen in female patients aged 80 and above. Five female patients aged above 90, were followed up with the diagnosis of CVD, while none of our male patients were older than 90 years of age.

Alzheimer's disease increases with age. In a study performed with patients above 50 years of age prevalence of Alzheimner's disease was detected as 11.0 percent $[18,19]$. In another study Alzheimer's disease was found in $30.4 \%$ of the people aged 75 years, and above [20]. In our investigation, Alzheimer's disease ranked third among our patients. In our study, the rates of Alzheimer's disease increased with age. Alzheimer's disease was mostly seen in patients aged 80 , and above. In both genders, number of patients aged 80 , and above were significantly higher than those seen in younger patients.

Decubitus ulcer is an important health problem which can emerge in bedridden patients. Decubitus ulcer increases mortality, and morbidity, and decreases quality of life of the patients. It also increases frequency of long-term immobility [21]. In another study, decubitius ulcer was reported in $12.0 \%$ of the patients receiving health care services at home [9]. However in our study lesser number
$(7.6 \%)$ of our patients had decubitus ulcer. Because of frequent provision of health care services to these patients, they have a special place as for home health care units. The staff of the Home Health Care Unit visit these patients at their homes, and dress their wounds every other day which have an important place in the Unit's workload not mentioning economic burden as for the utilization of material, cost of drugs used, and wound care expenditures. Therefore, as an important issue, Health Care Service Units should train the patient's household about applications against occurrence of decubitus ulcer.

In this study where demographic characteristics, and diseases seen in the patients who were receiving home care were evaluated, generally outcomes similar to those seen in other studies have been obtained. In our study, the need for health care services at home is especially crucial for bedridden patients with cardiovascular diseases, senility, Alzheimer's Disease, and musculoskeletal diseases. Structuring home health care service units, and training their staff so as to ensure treatment, and rehabilitation of these patients who need long-term care can be realized at their home environment will be an appropriate approach.

Conflict of Interest: No conflict of interest was declared by the authors.

Financial Disclosure: The authors declared that this study has received no financial support.

\section{REFERENCES}

1. Bahar A, Parlar S. Yaşlilık ve Evde Bakım. Fırat Sağlık Hizmetleri Dergisi 2007;4:32-9.

2. Evde Bakım Hizmetleri Sunumu Hakkında Yönetmelik. Available at: http://www.saglik.gov.tr/TR/belge/1-570/ evde-bakim-hizmetleri-sunumu-hakkinda-yonetmelik.html. Accessed mart 10, 2005.

3. Evde Sağlik Hizmetleri Yönergesi. Available at: http://www. saglik.gov.tr/TR/belge/1-12133/saglik-bakanliginca-sunulan-evde-saglik-hizmetlerinin-u-.html. Accessed Şubat 1, 2010.

4. Aydın D. Evde Bakım Hizmetleri. Sağlıklı Nesiller Derneği Sağlık ve Eğitim Yayınları 2005;1:20-1.

5. Karahan A, Güven S. Yaşlilıkta Evde Bakım. Turk J Geriatrics 2002;5:155-9.

6. Yardım N. Yaşlanma ve kronik hastalıklar; Türkiye perspektifi. Halk Sağlığı Uzmanları Derneği Yaşlı sağlığı: Sorunlar ve 
çözümler 2012;1:60-5.

7. Akdemir N, Bostanoğlu H, Yurtsever S, Kutlutürkan S, Kapucu S, Özer ZC. Yatağa bağımlı hastaların evde yaşadıkları sağlık sorunlarına yönelik evde bakım hizmet gereksinimleri. Dicle Tip Dergisi 2011;38:57-65.

8. Global burden of neurological disorders estimates and projections, Available at: http://www.who.int/mental_health/neurology/ neu rology/ chapter_2_neuro_disorders_public_h_challenges.pdf. Accessed June 10, 2008.

9. Enginyurt Ö, Öngel K. Evde bakım hizmeti kapsamındaki hastaların sosyodemografik özellikleri ve tıbbi durumları. Smyrna Tip Dergisi 2011;45-8.

10. Cindoruk M, Yetkin İ, Şahin M, Ekici E, Görgül A, İleri F, ve ark. Evde Bakım Hizmetleri. Akad Geriatri 2010;2:121-7.

11. Arslantaş D. Halk Sağlığı Bakışıyla Evde Bakım Hizmetleri; Durum Tespiti. Halk Sağlı̆̆ı Uzmanları Derneği Yaşlı sağlığı: sorunlar ve çözümler 2012;1:80-6.

12. Kamenski G, Fink W, Maier M, Pichler I, Zehetmayer S. Characteristics and trends in required home care by GPs in Austria: diseases and functional status of patients. BMC Fam Pract 2006;7:55. CrossRef

13. Taşdelen P, Ateş M. Evde Bakım Gerektiren Hastaların Bakım Gereksinimleri ile Bakım Verenlerin Yükünün Değerlendirilmesi. Hemşirelikte eğitim ve araştırma dergisi 2012;9:22-9.
14. Pınar R. Türkiyéde evde bakımda mevcut durum. Akademik Geriatri Dergisi 2010:153-6.

15. Yesilot NF, Koyuncu BA, Coban O, Tuncay R, Bahar SZ. Gender differences in acute stroke: Istanbul medical school stroke registry. Neurol India 2011;59:174-9. CrossRef

16. Gökçe-Kutsal Y, Eyigör S. Klinisyen gözüyle yaşl1lık döneminde sık görülen hastalıklar. Halk Sağlığı Uzmanları Derneği Yaşlı Sağlığı: sorunlar ve çözümler 2012;1:48-59.

17. Akgün S, Rao C, Yardim N, Basara BB, Aydin O, Mollahaliloglu $S$, et al. Estimating mortality and causes of death in Turkey: methods, results and policy implications. Eur J Public Health 2007;17:593-9. CrossRef

18. Isik AT. Late onset Alzheimer's disease in older people. Clin Interv Aging 2010;5:307-11. CrossRef

19. Gurvit H, Emre M, Tinaz S, Bilgic B, Hanagasi H, Sahin H, et al. The prevalence of dementia in an urban Turkish population. Am J Alzheimers Dis Other Demen 2008;23:67-76. CrossRef

20. Arslantaş D, Ozbabalik D, Metintaş S, Ozkan S, Kalyoncu C, Ozdemir G, et al. Prevalence of dementia and associated risk factors in Middle Anatolia, Turkey. J Clin Neurosci 2009;16:1455-9.

21. Dündar D, Keçeli Özcan S, Atmaca E. Evde Bakım Hizmeti Verilen Hastaların Bası Yaralarındaki Yüzeyel Kolonizasyonun Mikrobiyolojik İncelenmesi. Kocatepe Trp Dergisi 2012;13:2732. 